\title{
Evolution of International Stock and Bond Market Integration: Influence of the European Monetary Union
}

\author{
Suk-Joong Kim \\ Fari Moshirian $^{1}$ \\ Eliza Wu \\ School of Banking and Finance, University of New South Wales, Sydney, NSW 2052, Australia.
}

\begin{abstract}
This paper examines the dynamic relationship between daily stock and government bond returns of selected countries over the past decade to infer the state and progress of interfinancial market integration. We proceed to empirically investigate the influence of the European Monetary Union (EMU) on time-variations in inter-stock-bond market integration/segmentation dynamics using a two-step procedure. First, we document the downward trends in time-varying conditional correlations between stock and bond market returns in European countries, Japan and the US. Second, we investigate the causality and determinants of this interdependent relationship, in particular, whether the various macroeconomic convergence criteria associated with the EMU have played a significant role. We find that real economic integration and the reduction in currency risk have generally had the desired effect on financial integration but monetary policy integration may have created uncertain investor sentiments on the economic future of the European monetary union, thereby stimulating a flight to quality phenomenon.
\end{abstract}

JEL Classification: C32; E44; F3; G14; G15

Keywords: Euro, volatility, currency unions, stock-bond correlations, time-varying financial market integration, flight to quality, optimal currency area.

Final Draft: February 2005

\footnotetext{
${ }^{1}$ Corresponding author; email: f.moshirian@unsw.edu.au. We thank an anonymous reviewer and seminar participants in the School of Banking and Finance at UNSW for providing helpful comments on earlier drafts. All errors remain our own.
} 


\section{Introduction}

Financial market integration is a central theme in International Finance and the benefits of economic growth via risk sharing, improvements in allocational efficiency and reductions in macroeconomic volatility and transaction costs are all well accepted (see Prasad et al., 2003 and Baele et al., 2004). Whilst financial market integration encompasses many different aspects of the complex inter-relationships across various financial markets, we focus on the nature and extent of interdependence (co-movements) across daily asset returns. ${ }^{2}$ Whilst international integration within specific financial asset markets has received much attention, the subject of integration across different financial asset markets has not, despite its importance for investors’ asset allocation and portfolio risk management decisions. This study investigates stock and bond market integration over time within a common market jurisdiction as we are motivated by: recent developments on stock-bond return co-movements in financial economics; and the historical European Economic and Monetary union (EMU) experience. Co-movements in asset market returns provide indirect evidence on financial markets' expectations and their reaction to common information that are priced into different asset types. To our best knowledge, co-movements in stock and bond returns have not been previously interpreted in an inter-financial market integration context and to this end, our main contribution is in merging these two strands of literature to shed new light on both. Moreover, with the implementation of a currency union and associated stabilization of macroeconomic fundamentals in Europe, we also ask whether there have been any influences on the integration process between stock and bond markets as this has not been addressed in the existing market integration literature.

\footnotetext{
${ }^{2}$ Studies sharing this focus include Bekaert and Harvey (1995), Bracker et al. (1999), Karolyi and Stulz (1996) and Longin and Solnik (1995).
} 
The nature of stock-bond market co-movements has perplexed researchers in financial economics for years and there have been many attempts to understand their fundamental relationship. Existing stock-bond studies are generally in agreement on how stock and bond returns co-move over time but not why they co-move. Early studies to address the latter can be represented by Campbell and Ammer (1993) as they implicitly assume time-invariance in the stock-bond relation, and conclude that observed levels cannot be justified by economic fundamentals. In this thread, Engsted and Tangguard (2001) is relevant for the European markets. Most recently, researchers modeled the time-varying risk premia in their investigation and established that stock and government bond returns exhibit a modest positive correlation over a long horizon but the relationship is a dynamic one, meaning that the amount of portfolio diversification with a given asset allocation is constantly changing (see inter alia Connolly et al., 2005 and Fleming et al., 2003). In particular, Cappiello et al. (2003) and Scruggs and Glabadanidis (2003) investigate the asymmetric nature of stock and bond market conditional variances and their comovement. In the asset pricing vein, Ilmanen (1995) and Barr and Priestley (2004) suggest that world stock and bond markets are largely segmented and that further understanding of their joint behaviour is needed.

Informational linkages have formed the basis of most recent theoretical models on time-varying stock-bond return co-movements. There are two main channels through which information drives that relationship: 1) Common sources of information influencing expectations in both stock and bond markets at the same time and 2) Sources of information that only alter expectations in one market but spill over into the other market. Informational spillovers between the two markets are the crux of dynamic cross-market hedging studies (see Fleming et al., 1998 and Kodres and Pritsker, 2002) and the motivation behind analyzing comovements in stock and bond market liquidities and the interaction with returns, volatility and order flow in Chordia et al. (2005). It is argued that a shock in one asset market may generate 
cross-market asset rebalancing thereby generating volatility linkages. Generally, government bonds are deemed to be a safe haven for investors engaging in a "flight to quality" in times of financial turmoil. As investors substitute safe assets for their risky ones, bond and stock market returns become negatively correlated (see Chordia et al., 2005, Connolly et al., 2005 and Hartmann et al., 2004). Most recently, stock market uncertainty has been provided by Connolly et al. (2005) as a key explanation for the stock-bond return relation. They use implied volatilities from equity index options to reflect stock market uncertainty, emphasizing that this should be positively related to economic-state uncertainty in the sense of Veronesi (1999). In spite of existing work, the explanation for long-term co-movements in stock and bond returns remains conjectural.

In this paper, we contribute to the literature by interpreting stock-bond return comovements in a new light. They have traditionally been modeled as statistical contemporaneous correlations or covariances but have not been viewed as an integral aspect of inter-stock-bond market integration. Hence, we analyse the extent to which international stock-bond market integration has been influenced by the EMU by documenting and determining the conditional correlation dynamics between daily stock and bond returns in a bivariate EGARCH model from 2/3/1994 to 19/9/2003. Our main hypothesis is that economic policies directed at achieving convergence in exchange rates, monetary stance and the real economy (three channels which have characterized the degree of economic integration across countries with the EMU) have been relevant and critical common influences on the extent of systemic stock and bond market integration in Europe and the rest of the world. We utilize additional information captured in a seemingly unrelated regression (SUR) to evaluate the significance of these economic channels amongst seasonal effects.

Our new findings are i) as intra-stock and bond market integration with the EMU has strengthened in the sample period, inter-stock-bond market integration has trended 
downwards to zero and even negative mean levels in most European countries, Japan and the US, consistent with a flight to quality phenomena in international financial markets; ii) crossmarket volatilities have overall stabilizing effects but bond market return shocks have more influence; iii) the EMU has caused the inter-stock-bond market segmentation dynamics (in a Granger sense) only in European countries; iv) real economic integration with the EMU and reduction in currency risk with the introduction of the Euro have generally stimulated interfinancial market integration but increasing monetary policy convergence with the EMU may have created uncertain investor sentiments in the international financial system; and v) there is no evidence of calendar effects in international inter-stock-bond market integration, particularly the January and day of the week effect.

The remainder of this paper is organized as follows. Section 2 introduces the data used for documenting and explaining the dynamics of stock-bond market integration. Section 3 focuses discussion on model selection whilst Section 4 considers the progress of financial integration between stock and government bond markets over time. Section 5 investigates the causality and determinants of time varying integration across stock and bond markets. Finally, concluding remarks are made in Section 6.

\section{Data description and statistics}

\section{Daily Bond and Stock market returns}

Our empirical analysis is conducted for a sample set of countries that fall into two distinct groups: 1) Euro zone members that have adopted the Euro as a common currency France, Germany, Italy, and Spain having the largest and most developed financial markets in the EMU and 2) Non-Euro zone countries which comprise the UK, which has opted to stay out of the EMU and Japan and US as they are the world's other two major financial markets, enabling inferences to be made on the EMU's global impacts. 
We employ the national total market return share indices from Datastream International and total return government bond indices for maturities greater than 10 years obtained from Bloomberg for the two groups of countries. ${ }^{3}$ Government bonds with more than 10 years to maturity have been used to effectively match their duration with stocks, which are generally viewed as long-term investments. The indices are all in local currency units with daily frequency from 2 March 1994 to 19 September 2003, determined by the availability of daily bond market indices for all countries in the sample. The continuously compounded market returns examined in this study are measured as the natural logarithms of the ratios of closing index levels from one trading day to the next such that, $R_{i t}=\ln \left(P_{t} / P_{t-1}\right) \times 100$ for market $i$ on day $t$. Local (unhedged) currency returns are used in this study to investigate the impact of changes in exchange rate risk induced by the introduction of the Euro for domestic investors. Daily frequency is important as comovements in the stock and bond returns often change on a rapid basis as investors shift their domestic asset allocation. Weekly stock and bond return data have been used by Cappiello et al. (2003) to model cross-country stock-bond return correlations for a sample of European and Australasian countries and the US.

To provide some perspective on the data, Table 1 reports the statistical properties of the daily bond and stock market returns for each sample country and the (market capitalization) value weighted average for the Euro zone. The pre- and post-Euro sub-sample statistics are shown in panels A and B, respectively. ${ }^{4}$ Bonds have only outperformed stocks in the post-Euro period but were less volatile in both periods. This is consistent with major declines in world equity prices since the collapse of the technology boom in 2001. In the preEuro sub-sample period, stock returns exceeded average bond returns for all countries except

\footnotetext{
${ }^{3}$ Total return on bonds capture the coupon payments that are reinvested back into the bonds forming the index as well as bond price changes and similarly, total return indices on shares account for price changes and dividend reinvestments.
} 
Italy and Japan. These observations are all consistent with well-documented stylized facts on stock and bond returns (eg., see Connolly et al., 2005, Li, 2002 and Scruggs and Glabadanidis, 2003). The distributions of these stock and bond market returns are statistically non-normal, and the standardized return series are highly persistent and heteroskedastic on the basis of univariate i.i.d. tests. The significance of the bivariate i.i.d. test statistics for each pair of stock and bond index returns indicates that the first and second moments of these series move closely together. Henceforth, modeling of these return series must address the bivariate and fat-tailed nature of these distributions in addition to the high degree of univariate and bivariate serial correlations.

\section{Explanatory Variables}

The list of variable definitions and data sources used in this study for the real and monetary convergence and exchange rate stability criteria is shown in Appendix A. First, correlations in nominal short term interest rates, inflation and real short term interest rates proxy convergence in monetary policy, and second, the size of the trade sector, intra-regional trade integration and correlations in output and term structure and dividend yield changes proxy the degree of real economic integration. Our probe into the link between financial and economic integration in the vein of Fratzscher (2002) and Kim et al.’s (in-press) European stock market studies provide new insights on the potential determinants of stock and bond comovements. Lastly, we generate conditional exchange rate volatilities using univariate GARCH(1,1) estimations for the change in local currency : Euro exchange rates to capture past information in exchange rates. ${ }^{5}$

\footnotetext{
${ }^{4}$ Summary statistics are available for the full sample period upon request.

${ }^{5}$ The European Currency Unit (ECU) was used prior to the Euro’s launch. As a robustness check, rolling standard deviations over 3 month time windows were also used to proxy exchange rate volatility and there was no qualitative improvement in our regression results.
} 
Furthermore, we build on Connolly et al.’s (2005) study and use implied volatilities from equity index options as a proxy for economic uncertainty in the international financial system. We use the Chicago Board of Options Exchange (CBOE)'s volatility index (VIX) and the German DAX equity index (VDAX) for explaining inter-stock-bond market integration in the US and Japan and all the European countries respectively.

\section{Econometric Model}

This study aims to examine whether the establishment of the EMU has induced a dynamic change in inter-stock-bond market integration by making inferences from the behavior of their daily conditional volatility interdependencies and time-varying conditional correlations. There is existing support for the notion that market integration influences the conditional asset return generating process (see Bekaert and Harvey, 2003).

Whilst the use of conditional econometric models capable of capturing asymmetric volatility has proliferated in stock market studies, government bond markets have not been dealt with in the same way. ${ }^{6}$ As Scruggs and Glabadanidis (2003) strongly rejected symmetric models of conditional second moments for stock and bond returns, we model the joint return generating process of stock and bond markets with a bivariate exponential generalized autoregressive conditional heteroskedasticity (EGARCH) model incorporating a bivariate student's $t$ conditional density function for the innovation vector to explicitly account for positive and negative shocks and fat tails in returns. Previous studies have found that the logarithmic specification in Nelson's (1991) EGARCH model with a suitable distributional

\footnotetext{
${ }^{6}$ See Wu (2001) and references therein for a survey of asymmetric volatilities in stock market studies and tests of the leverage and volatility feedback effects.
} 
assumption fits financial data well. ${ }^{7}$ The advantage of employing the $t$-distribution is that the unconditional leptokurtosis observed in most high-frequency asset price data sets can appear as conditional leptokurtosis and still converge asymptotically to the Normal distribution as 1/D ( $D$ being the degrees of freedom) approaches zero (usually in lower-frequency data). This provides added flexibility to our methodology.

A bivariate EGARCH-t model with time-varying conditional correlations is a worthwhile methodological contribution to the existing stock-bond co-movement literature. The use of regime switching models in Connolly et al. (2005) requires volatility states to be probabilistically set and asymmetric dynamic conditional correlation models in Cappiello et al. (2003) and Scruggs and Glabadanidis (2003) are not so easy to interpret. Moreover, the EGARCH process is supported by the theoretical underpinnings of Fleming et al.'s (1998) trading model of informational linkages between stock and bond markets. Furthermore, crossmarket volatility interdependencies within individual countries have never been extensively investigated but in our bivariate EGARCH model for stock and bond market returns, the volatility spillover effects can be quantified to fill this gap in the literature. Existing studies have generally assessed volatility linkages and correlation dynamics in stock and bond markets outside of the US separately, to infer interdependence from the timing of changes in both markets (eg., Bodart and Reding, 1999 and Capiello et al., 2003).

We estimate conditional first moments (means) of the index returns as a parsimonious restricted bivariate autoregressive moving average, $\operatorname{ARMA}(p, q)$ process as shown in equations $(1 \mathrm{a}, \mathrm{b})$ to capture the dynamics between mean bond and stock market returns for each individual country and for completeness, the Euro zone (weighted average of the four EMU members).

\footnotetext{
${ }^{7}$ Formulation of logarithmic conditional variances also overcomes the need for non-negativity constraints to ensure positive definite covariance matrices.
} 


$$
\begin{aligned}
& R_{B, t}=\alpha_{B}+\sum_{i=1}^{p_{S}} \alpha_{r S, i} R_{S, t-i}+\sum_{j=1}^{q_{B}} m_{B, j} \varepsilon_{B, t-j}+\varepsilon_{B, t} \\
& R_{S, t}=\alpha_{S}+\sum_{i^{*}=1}^{p_{B}} \alpha_{r B, i^{*}} R_{B, t-i^{*}}+\sum_{j^{*}=1}^{q_{S}} m_{S, j^{*}} \varepsilon_{S, t-j^{*}}+\varepsilon_{S, t}
\end{aligned}
$$

where, $R_{B, t}$ and $R_{S, t}$ are the bond and stock market conditional mean returns respectively, that are functions of past cross-market returns and its own past idiosyncratic shocks. To prevent over-identification, the bivariate ARMA has been restricted such that past cross-market performance and past own market performance is captured by AR and MA terms respectively. Note that $p_{B}$ and $p_{S}$ are the number of autoregressive terms and $q_{B}$ and $q_{S}$ are the number of moving average terms needed to eliminate univariate and bivariate serial correlations in the standardized residuals, $\frac{\varepsilon_{B, t}}{\sqrt{h_{B, t}}}$ and $\frac{\varepsilon_{S, t}}{\sqrt{h_{S, t}}}$, which are jointly $t$ distributed.

The conditional second moments (variances) of the estimated model are estimated as:

$$
\begin{aligned}
& \ln h_{B, t}=\beta_{C B}+\beta_{h B} \ln h_{B, t-1}+\left[\beta \varepsilon_{B 1} \frac{\varepsilon_{B, t-1}}{\sqrt{h_{B, t-1}}}+\beta \varepsilon_{B 2}\left(\frac{\left|\varepsilon_{B, t-1}\right|}{\sqrt{h_{B, t-1}}}-\sqrt{\frac{2}{\pi}}\right)\right]+\left[\beta_{S 1} \frac{\varepsilon_{S, t-1}}{\sqrt{h_{S, t-1}}}+\beta_{S 2}\left(\frac{\left|\varepsilon_{S, t-1}\right|}{\sqrt{h_{S, t-1}}}-\sqrt{\frac{2}{\pi}}\right)\right] \\
& \ln h_{S, t}=\beta_{C S}+\beta_{h S} \ln h_{S, t-1}+\left[\beta \varepsilon_{S 1} \frac{\varepsilon_{S, t-1}}{\sqrt{h_{S, t-1}}}+\beta \varepsilon_{S 2}\left(\frac{\left|\varepsilon_{S, t-1}\right|}{\sqrt{h_{S, t-1}}}-\sqrt{\frac{2}{\pi}}\right)\right]+\left[\beta_{B 1} \frac{\varepsilon_{B, t-1}}{\sqrt{h_{B, t-1}}}+\beta_{B 2}\left(\frac{\left|\varepsilon_{B, t-1}\right|}{\sqrt{h_{B, t-1}}}-\sqrt{\frac{2}{\pi}}\right)\right]
\end{aligned}
$$

which permits the conditional variance of each asset market to be determined by its own past variance and its own negative and positive past unanticipated return shocks (coefficients on these terms indicate the asymmetric and volume effects respectively) as well as those return shocks from the other asset market. We incorporate volatility spillover effects in the conditional variances in modeling joint stock and bond market returns as we are interested in their cross-market volatility interdependencies and this has not been previously investigated using estimated parameter values. Importantly, the conditional covariance between bond and stock market returns are allowed to vary across time to capture the time-varying nature of the integration process. This is not only theoretically justified by the dynamic nature of market integration but it also builds on Scruggs and Glabadanidis' (2003) rejection of a constant 
correlation restriction on the covariance matrix between US stock and bond returns. The conditional covariance equation used is shown below: ${ }^{8}$

$$
h_{B S, t}=\delta_{0}+\delta_{1} \sqrt{h_{B, t} \cdot h_{S, t}}+\delta_{2} h_{B S, t-1}
$$

where the dynamics have been modeled based on the cross-product of standard errors of the stock and bond market returns and past conditional covariance. Hence, by definition the time-varying conditional correlations can be computed as in equation (4) and can be used to indicate the level of co-movement between stock and bond market returns. We interpret this contemporaneous conditional correlation time series to provide a historical time path for the integration process between stock and bond markets due to the pricing of common information that is reflected in this measure at any point in time.

$$
\rho_{B S, t}=\frac{h_{B S, t}}{\sqrt{h_{B, t} \cdot h_{S, t}}}
$$

\section{International Stock-Bond market integration: Country level evidence}

In this section, we show the evolution of international stock and bond market integration in and outside of the EMU over the sample period. Whilst stock and bond return co-movements have been assessed by Scruggs and Glabadanidis (2003) using US data; and regional and cross-country stock-bond return correlations have been analyzed by Cappiello et al. (2003) using the EMU, Australasia and the US, there has not been an extensive international study on stock-bond-market co-movements at the country level.

\footnotetext{
${ }^{8}$ Various alternative covariance structures, including Engle’s (2002) Dynamic Conditional Correlation and Darbar and Deb's (2002) LEGARCH specifications, were estimated in addition to the current form to ensure that the results obtained were robust to different functional forms for the conditional covariance parameterization. In general, alternative specifications made no qualitative differences to our time-varying conditional correlations from the bivariate EGARCH- $t$ model.
} 


\subsection{Time-varying Conditional Correlations: Cross-market and with the EMU}

Figure 1 shows the graphs of the estimated dynamic inter-stock-bond conditional correlations for each sample Euro zone country (on the left-hand column) and the weighted average of these Euro countries and also non-Euro zone countries (on the right-hand column). ${ }^{9}$ There are significant variations in the conditional correlations of stock and bond returns over the sample period. The most striking conclusion from these graphs is that since the mid 1990s integration has been falling between these two major financial segments in Europe and in the rest of the world to zero mean levels (consistent with the behavior of Cappiello et al.’s, 2003 regional level stock-bond correlations over the same time period), with the exception in Italy where co-movements between the two markets have been strengthening since 2000 and Japan where the series has gyrated around a low negative level (around -0.2). This is new country-level evidence on European cross-market integration as Cappiello et al. (2003) previously assessed cross-country inter-stock-bond correlations between Germany, France, Italy and the UK and found strong increases between all EMU countries around 1999 when the Euro was introduced. This sustained period of inter-stockbond market segmentation cannot be attributed to the demise of the tech bubble in the late 1990s as it began earlier in the decade. Instead, it can perhaps be explained in the context of a flight to quality hypothesis: investors' uncertainty in the future of the EMU and the macroeconomic fundamentals under the new exchange rate regime has resulted in investors flocking to the government bond markets (perceived safe havens) as evidenced by the declining correlations in bond and stock returns. This is certainly plausible given the poor economic performance of the larger member countries since the EMU's inception. However,

\footnotetext{
${ }^{9}$ A caveat of this analysis is the implicit assumption of same risk levels associated with investing in stocks and government bonds. Hence, the EGARCH model has also been estimated with excess stock returns (risk premia) to adjust for this and the results are qualitatively similar for most countries.
} 
for the historically volatile Italian financial markets, the monetary union has instead been perceived by investors in the post-Euro time period to reduce macroeconomic uncertainty and has thus increased co-movements between stock and bond returns. This is supported by Morana and Beltratti's (2002) finding that Italy’s stock market volatility has dampened with the introduction of the Euro. These two explanations are also consistent with the fundamental approach represented by Campbell and Ammer (1993) in which a differential response to inflation expectations in the pricing of these two securities may induce low correlations as inflation is generally viewed as bad news for bonds and ambiguous news for stocks. Furthermore, consistent with the stylized fact of negative stock and bond return correlations in times of financial turmoil (eg., see Chordia et al., 2005 and Hartmann et al., 2004) it is not surprising that Japan exhibits a stable negative correlation level over the sample period given its enduring financial problems over the sample period. Finally, using stock-bond return correlations over consecutive periods, Connolly et al. (2005) showed negative correlations were more likely when stock market uncertainty (ie. economic uncertainty) was high. This also lends support for our explanations.

Probing further into the EMU's influence on our observed segmentation trend in international stock-bond markets, we provide some evidence on how the two individual financial segments have been integrating with the EMU region in Figure 2. We estimate a similar bivariate EGARCH-t model with time varying conditional correlations but using national and value-weighted Euro zone asset returns instead of same country bond and stock returns. ${ }^{10}$ Hence, in Figure 2 the historical path of conditional correlations between bond market returns are shown on the left hand side column (to proxy intra-bond market integration

\footnotetext{
${ }^{10}$ To avoid spurious integration results from the bivariate EGARCH estimations, we generated EMU regional indices separately for stock and bond markets that excluded individual sample EMU countries in the weighted average calculation.
} 
with the EMU) and those for stock market returns are depicted on the right hand side column (to proxy intra-stock market integration with the EMU). ${ }^{11}$

In Figure 2, it is clear that international stock markets had rapidly integrated with EMU stock markets in the few years leading up to the introduction of the Euro, corroborating with Fratzscher's (2002) and Kim et al.’s (in-press) stock market integration studies and increases in Cappiello et al.'s (2003) average contemporaneous correlation calculations for stock markets. However, compared to the series of intra-stock market conditional correlation charts, those for intra-bond markets are relatively heterogeneous. By construction, the four Euro zone bond markets are highly correlated with the Euro zone regional bond index return as evidenced by the extremely high conditional correlation levels (ranging from 0.65 to almost 1.0). However, the synchronization of monetary policy with the introduction of the Euro has no doubt also contributed to this. Not surprisingly, outside of the Euro zone the UK's government bond market is the most correlated with the core Euro zone market index (correlations range $0.68-0.75)$, followed by the United States $(0.38-0.48)$ and then Japan $(0.03-0.09)$. There has generally been an upward trend in intra-bond market integration with the core Euro zone in part of the sample period for all sample countries. For the four EMU countries, bond markets had become integrated even before the stock markets but they appear to have plateaued from mid 1998. This is consistent with existing European financial market studies that generally find the single currency had influenced government bond markets in the EMU even before the Euro was officially launched in 1999 (eg, see Galati and Tsatsaronis, 2003). Outside of the EMU, the UK, US and Japanese bond markets have been slower to integrate with the EMU but a slight upward trend has emerged as the new exchange rate regime became imminent. This is also supported by increases in Cappiello et al.'s (2003)

\footnotetext{
${ }^{11}$ The underlying estimation results for intra-market integration with the EMU are not reported here due to space considerations but are available upon request from the corresponding author.
} 
average correlation calculations for bond markets. While international stock and bond markets have become more intricately linked with the Euro zone markets, this international financial development has segmented stock and bond markets at the country level. This suggests that macroeconomic developments associated with the EMU should explain inter-stock-bond market integration dynamics.

\subsection{Estimation results for international stock and bond returns: Volatility linkages}

The bivariate estimation results for the EGARCH- $t$ model with volatility spillovers are shown in Table 2 . The coefficients for the lagged conditional variance terms ( $\beta_{\mathrm{hB}}$ and $\beta_{\mathrm{hS}}$ ) are very close to one for all pairs of bond and stock market returns indicating a high level of persistence in shocks to the conditional volatility and hence, the appropriateness of a GARCH framework. ${ }^{12}$ The diagnostics for our maximum likelihood estimations are provided at the bottom of Table 2. The joint conditional $t$ density function assumed for the innovations converged asymptotically to the Normal distribution as 1/D (D being degrees of freedom) was very close to zero in all cases. ${ }^{13}$ The Ljung Box Q statistics show that both univariate and bivariate serial correlation was successfully removed for all countries, eliminating potential biases in our estimates. The high level of significance for estimates in the covariance equations (shown in Table 2) strengthens our confidence in the validity of the conditional correlation time series illustrated in Figure 1.

Whilst the conditional volatility of stock market returns display significant asymmetric and volume effects with the appropriate signs for its own return shocks, bond market conditional volatility generally does not exhibit an asymmetric response to its own

\footnotetext{
${ }^{12}$ As a robustness check, this model was also estimated with the conditional variance included in the mean equations (EGARCH-M) but these terms were found to be insignificant for most sample countries.
} 
unexpected shocks. This is consistent with Scruggs and Glabadanidis (2003) and Cappiello et al. (2003) but our bivariate EGARCH methodology is better able to quantify both asymmetric (sign) and volume (magnitude) effects on conditional variances as we can interpret estimated parameters instead of relying on the shape of news impact surfaces. Fundamentally, our results are consistent with these previous studies on conditional stock-bond co-movements but our new findings emanate due to different time periods, sample countries and methodologies used. Whilst we find conditional stock market volatilities are relatively more responsive to bond market return shocks than conditional bond market volatilities are to stock market return shocks, we also find that bond market conditional variances are not completely unresponsive to stock return shocks. The asymmetric effect is significantly positive for Japan and the US and the volume effect is significantly negative for Spain and the UK which is contrary to the well-known findings for stock markets and is a new result with an international aspect. This pattern in cross-market return shocks is repeated more strongly for conditional stock market variances. This means that generally, an unexpected rise in one asset market has a bigger stabilizing effect on the other asset market's conditional volatility than unexpected falls but this is offset to some extent by systemic rises in financial market volatility when there is a shock in either market. This new result on cross-market volatility interdependence supports the flight to quality hypothesis as it provides indirect evidence that when positive news hits one asset market, volatility is dampened in the other as investors tend to stick with their asset allocations but when negative news hits, investors tend to switch towards perceived 'quality' investments thereby increasing cross-market volatility.

Furthermore, we find that cross-market volatility spillovers are mostly unilateral for Euro zone markets in that only shocks in bond returns affect stock market volatility and not

\footnotetext{
${ }^{13}$ A normal log density function was also assumed but there was little difference in the estimates due to the joint student $t \log$ density's ability to accommodate normal distributions.
} 
vice versa. However, for non-Euro financial markets, volatility spillovers are bilateral in that unanticipated return shocks in both bond and stock markets affect the other. This is another new finding in our country level study and suggests that common information affects nonEuro stock and bond markets simultaneously whilst in the Euro zone, information appears to change expectations in the bond market initially and this is then transmitted to stock markets, perhaps through portfolio rebalancing. A key explanation for this is the common sensitivity of EMU bond markets to the official level of interest rates (monetary policy stance) set by the European Central Bank for all EMU members and this result has clear policy implications.

In Table 2, the coefficients on lagged mean cross-market returns are generally significant and positive indicating positive return spillover effects between bond and stock markets. This is also consistent with the flight to quality phenomenon as when stock market returns fall, investors tend to flock and bid up the price of government bonds and the inverse relationship with yields will cause a subsequent fall in bond returns to result. Hence, we find support for the flight to quality explanation for the financial segmentation between stock and bond markets on the basis of estimated return and volatility linkages in our bivariate EGARCH-t model. In the rest of this paper, we determine the underlying macroeconomic forces at play in driving the international stock and bond market integration/segmentation process over the sample period associated with the formation of the EMU.

\section{EMU influence on International Stock-Bond market integration}

First, we test for causality between the European currency unification experience and international stock-bond market integration to facilitate our context and modeling strategy. As seen in Table 3, there exists uni-directional causality from the EMU to the inter-stock-bond market integration in only European countries. The Italian stock and bond markets have not exhibited segmentation dynamics like those in the other Euro zone members and it is 
interesting that the formation of the EMU has not been necessary for its inter-stock-bond market developments. The causality result for the UK is largely consistent with the EMU members and this is not surprising given that they are affected by many common economic factors. The implications of these results for policy makers is that by conforming with the new exchange rate regime, they have created improved diversification benefits in international stock and bond markets as suggested by the causal relationship with the observed declining integration series.

Our simple analysis provides new findings for inter-market integration both in and outside of the EMU. Next, we account for the predictive ability of the EMU in the next section by replacing the EMU proxy with variables adopted from the Optimal Currency Area (OCA) literature in a seemingly unrelated regression estimation (SURE). It has been recognized in the literature that what drives time variations in financial market integration may not be a country's own fundamentals but also the degree of real and financial convergence with other economies (see Fratzscher, 2002). The EMU has involved tremendous convergence on many different macroeconomic facets and these are well captured by the range of assessment criteria used in Optimal Currency Area (OCA) analyses, some of which have been applied by Fratzscher (2002) and Baele (2005) to assess European stock market integration. We extend from this work and conduct principal component analyses for the broad economic channels through which the EMU may have played a role on financial market integration: real integration, monetary policy convergence and exchange rate risk reduction. We expect a priori on the basis of OCA theory that as economies become more alike, the benefits of a monetary union increases. As Mamaysky (2002) notes, if a given set of explanatory variables is truly important for determining joint stock-bond returns, they must represent a risk that is priced in the economy and it is on this ground that these may be potential determinants of stock-bond integration dynamics. 
We found a high degree of multicollinearity between the various OCA criteria adopted in this study. This is not surprising given that the convergence in the real economies and monetary policies did not occur in isolation during the European currency unification process. Like Fratzscher (2002) we overcome potentially spurious regression results by forming two principal components to represent the variables which combine to proxy these two different facets of economic integration.

We subsequently incorporate these two principal component variables, exchange rate volatility and a January dummy variable into a pooled cross-sectional time series SURE to gauge the influence of macroeconomic convergence on dynamic financial market integration. This is a technique which has not previously been applied to explain bond-stock comovements but it makes intuitive sense in our investigation. Our implicit assumption by using SURE is that the residuals in our system of linear equations are contemporaneously correlated at any point in time because they are capturing similar omitted factors on each country's financial integration process. These may include regulatory barriers, political, institutional, legal, social and cultural factors, posing additional information normally omitted from separate OLS estimation. Hence, we make use of the contemporaneous correlation assumption and jointly estimate a system of seven equations (one for each sample country) within a generalized least squares (GLS) framework to improve our estimates. ${ }^{14}$ The SURE results for the following model are shown in Table $4 .{ }^{15}$

\footnotetext{
${ }^{14}$ The correlation matrix for residuals from each individual country in the SUR system of equations reveal that correlations are of sufficient magnitude to warrant SUR over separate least squares estimation. Separate OLS regressions were run for a comparison and these are available upon request from the authors.

${ }^{15}$ a) This model controls for the predictability of integration levels based on Granger causality test results by including lagged instead of contemporaneous explanatory variables. Information variables (dividend yield -DIV, short-term interest rate - ST_IRATE and term structure - TERM) have also been used as controls in this regression model because of their well-known predictive ability for stock and bond returns (see Scruggs and
} 


$$
\begin{aligned}
& \rho_{B S i, t}=\alpha_{1 i}+\alpha_{2 i} E X_{-} V O L_{i, t-1}+\alpha_{3 i} R E A L_{-} I N T_{i, t-1}+\alpha_{4 i} M O N_{-} I N T_{i, t-1} \\
& +\alpha_{5 i} J A N_{-} D U M_{i, t}+\alpha_{6 i} \rho_{B S i, t-1}+\alpha_{7 i} \rho_{B S i, t-2}+u_{i t}
\end{aligned}
$$

where the dependent variable ( $\rho_{B S i, t}$ ) is the conditional bond-stock correlation series for each country i \{France, Germany, Italy, Spain, UK, Japan, US $\}, E X_{-} V O L_{i, t-1}=$ lagged conditional exchange rate volatility, $R E A L \_I N T_{i, t-1}=$ lagged real economic convergence, $M O N \_I N T_{i, t-1}=$ lagged monetary policy convergence and $J A N \_D U M$ is the January dummy variable, and $\rho_{B S i, t-1}$ and $\rho_{B S i, t-2}$ are the first and second lags of the dependent variable.

As with most cross-country studies, there are slight differences with respect to the significance of the explanatory variables across sample countries in our SUR system. However, the fact that the three macroeconomic variables of interest are not all significant for each individual country suggests that we have been successful in orthogonalizing the EMU's channels of influence. Firstly, reductions in conditional foreign exchange volatilities have only been important to bond and stock market interdependencies in Germany and Japan. We believe this makes intuitive sense given that exchange rates have been required to fluctuate within narrow bands from a basket of European currencies (ECU) since 1979 and this already made the Euro a close substitute for the currencies of most European countries. However in line with our expectations based on OCA theory and Fratzscher's (2002) stock market findings, reductions in exchange rate volatility have only been effective in stimulating stock and bond market integration (and not segmentation) in our sample countries (as indicated by

Glabadanidis, 2003). However, the results are not significantly different without them and we overcome the problem of multicollinearity as they are used in constructing the macroeconomic convergence principal components.

b) Augmented Dickey Fuller test statistics on inter-stock-bond integration levels in Table 4 rejected the presence of a unit root at the conventional 5\% level of significance indicating stationarity in all cases. 
their significant and negative coefficients). The weak contribution of exchange rate risk reduction to the integration of stock and bond markets is consistent with Bodart and Reding's (1999) finding that correlations in stock and bond returns in Europe were not very sensitive to changes in the Exchange Rate Mechanism and also De Santis et al.'s (2003) finding that adoption of the Euro did not have a large impact on aggregate currency risk premia. Secondly, real economic integration also appears to have played a significant role in steering stock and bond markets towards further integration within the EMU and with Japan and the US (positive coefficient) as OCA theory would dictate. Thirdly, monetary policy convergence (inferred from inflation, nominal and real short term interest rates) is only a positively significant determinant of inter-bond and stock market integration in Italy (where there has been the only sign of an upward trend in integration between these two financial segments as Figure 1 revealed). This suggests that a combination of monetary policy changes in the past decade may be the culprit in inducing investor uncertainty on the future of the EMU thereby creating a flight to quality investments in other sample countries. We investigated this possibility further in sub-sample estimations where we found clear negative signs on most coefficients and in subsequent analysis on economic uncertainty. However, corroborating with this argument is the finding by Chordia et al. (2005) that co-movements in stock and bond market liquidity are driven by monetary shocks and also Li’s (2002) empirical results indicate the major trends in stock-bond correlations are determined by uncertainty on expected inflation. Fourthly, we find no evidence of seasonality (January or day of the week effects) in bond and stock market integration dynamics, especially outside of the US. This finding is not surprising given the amount of mixed evidence on seasonality outside of equity markets (eg., see Smith, 2002) but this is still a new international result given that calendar regularities have been found in stock and bond market liquidity by Chordia et al. (2005) using intraday US data. Finally, we find that stock and bond market integration/segmentation is a 
persistent process as indicated by the highly significant lagged dependent variable terms for most sample countries and this is consistent with serial correlations found in stock-bond correlations by Li (2002). ${ }^{16}$

A Chow test is conducted to test for structural change in estimated parameters pre- and post-Euro introduction. The Chow test involved a test of the joint significance of the entire set of additional interactive dummies in the regression (regressors multiplied by a Euro time dummy that took the value of one from 1 January 1999 onwards and zero prior to that). The null hypothesis of no structural change in the estimates was rejected, justifying separate regressions for a pre- and post-Euro sub-sample period to gauge the changing importance of the three main economic channels in explaining bond and stock market integration/segmentation. ${ }^{17}$ The sample split is informative in that it reveals that the reduction in exchange rate volatility was effective in fostering European inter-bond and stock market integration in the lead up to the Euro's introduction but not since then. On the other hand, real economic integration has only been stimulatory for inter-stock-bond market integration in the post-Euro era, as prior to the introduction of the single currency it had generally contributed to the segmentation of stock-bond markets. As mentioned before, monetary policy convergence has been a pervasive deterrent to stock-bond market integration as suggested by the negative coefficients observed in both sub-samples.

\footnotetext{
${ }^{16}$ We present Ljung Box Q tests for serial correlation as it can be used in the presence of lagged dependent variables without any bias towards the finding of no serial correlation. On the basis of these Q statistics it can be seen that serial correlation has been successfully removed in most equations with two autoregressive terms.

${ }^{17}$ A Euro dummy was also significant in a full sample regression but its omission reduces multicollinearity between regressors. Sub-sample results have been omitted due to space constraints but are available on request.
} 


\section{International Stock-Bond market segmentation and Economic uncertainty}

Segmentation between bond and stock markets is now a persistent process in most of Europe and the rest of the world driven perhaps due to continued uncertainty about the economic and financial future of the International Monetary System.

In the financial economics literature, implied volatilities are generally accepted as a good proxy for the time-varying uncertainty associated with the expected future stochastic stock volatility. Connolly et al. (2005) provides convincing empirical evidence on the influence of stock market uncertainty measures on time-variations in the co-movements of stock and government bond returns, motivated by the seminal work of Veronesi (1999) on time-varying stock market uncertainty being a reflection of economic uncertainty. It is argued that in a state of higher economic uncertainty, new information may receive higher weighting in the stock price formation process, leading to time-variations in stock market volatility.

Extending Connolly et al. (2005), we apply a stock market uncertainty measure to investigate the influence of economic state uncertainty on time-variations in stock and bond market integration/segmentation dynamics. Thus, we use the CBOE’s Volatility Index (VIX) and the implied volatility index from the DAX (VDAX) as a proxy for economic uncertainty in our sample countries and sample period. As an increase in these implied volatility indices are generally viewed by market participants as a sign of increasing aversion to uncertainty, we expect $a$ priori a negative relationship between the lagged levels of economic uncertainty and the integration between stock and bond markets. Hence, we estimate the following model for each country to investigate the explanatory power of economic uncertainty in driving interstock-bond integration dynamics:

$$
\rho_{B S i, t}=\beta_{1 i}+\beta_{2 i} \operatorname{Ln}\left(\text { uncert }_{t-1}\right)+\beta_{3 i} \rho_{B S i, t-1}+\beta_{4 i} \rho_{B S i, t-2}+\mu_{i, t}
$$

where the dependent variable ( $\rho_{B S i, t}$ ) is the conditional bond-stock correlation series for each country i $\left\{\right.$ France, Germany, Italy, Spain, UK, Japan, US\}, Ln(uncert $\left.\mathrm{t}_{-1}\right)$ is the natural 
logarithm of the lagged implied volatilities from equity index options and $\rho_{B S i, t-1}$ and $\rho_{B S i, t-2}$ are the first and second lags of the dependent variable to reduce serial correlation.

OLS estimations ${ }^{18}$ revealed that for all countries except Italy, the coefficient on the uncertainty variable is negative and significant at the $1 \%$ level lending further support to the account that it is uncertainty on the economic future of the international financial system which is driving segmentation in international stock and bond markets. In the EMU, the recent change in exchange rate regime is more than likely to have contributed to the region's economic and financial uncertainties but it is clear that its influence reaches internationally. This is a new interpretation and confirms Connolly et al.'s (2005) results using the US and other G7 countries, that there is an international aspect to the inverse relationship between stock market uncertainty and stock-bond market co-movements. Economic uncertainty in the international monetary system is causing a prolonged flight to quality investments (less extreme than investor reactions in financial crises) and this is improving diversification benefits between stocks and bonds at the country level. Italy is the only country where interstock-bond market integration has recently increased and the coefficient on the uncertainty variable is positively significant suggesting that economic uncertainty associated with the EMU has not triggered the same response in its bond and stock markets.

\section{Conclusions}

The aim of this paper is to investigate whether time-varying co-movements between daily government bond and stock returns over the past decade have been affected by the implementation of the EMU. We find that as intra-stock and bond market integration with the EMU has strengthened in the sample period, inter-stock-bond market integration at the

\footnotetext{
${ }^{18}$ The OLS results for equation (6) are available upon request from the corresponding author but have been omitted due to space constraints.
} 
country level has trended downwards to zero and even negative mean levels in most European countries, Japan and the US - consistent with a flight to quality phenomena in international financial markets. We find further evidence to support this in estimated sign and volume effects on cross-market volatility spillovers in a bivariate EGARCH model and we note that bond market return shocks have more influence than stock market shocks consistent with existing literature. There is convincing evidence that the introduction of the monetary union has Granger caused the apparent segmentation between bond and stock markets within Europe but not outside. Moreover, real economic integration with the EMU and reduction in currency risk with the Euro have generally stimulated inter-financial market integration but the adoption of a common monetary policy may have brought about investor concerns on the future of macroeconomic fundamentals in Europe and the international financial system, inducing a flight to government bonds, a perceived safe haven asset. To this end, the EMU has increased benefits of diversification across stocks and government bonds at the country level. There are no clear seasonal patterns in inter-market integration/segmentation dynamics between daily government bond and stock returns in this international study.

We have made significant contributions to the broad finance literature on many levels, including i) providing a new application of stock-bond co-movements to proxy inter-financial market integration over time; ii) illustrating a two-step methodology that is suitable for this new application; iii) using higher frequency (daily) data to investigate international stockbond co-movements; iv) improving understanding on cross-market conditional volatility interdependencies and correlations at the country level; v) establishing the direction of causality for inter-financial market integration and monetary union adoption; and vi) providing an alternative theoretical explanation for stock-bond co-movements by using macroeconomic convergence criteria associated with optimal currency area studies and 
reinforced with a robust stock market uncertainty measure to study international inter-stockbond market integration.

This paper has important implications for both investors and policy makers. For investors, inter-stock-bond market segmentation at the country level means that diversifications benefits have increased for even domestic asset allocations. For policy makers, the process of monetary policy coordination is creating heightened economic uncertainty in financial markets and financial system instability may become more pronounced as asset markets of the same type become more interdependent and asset markets in the same jurisdiction continue to react to those developments. 


\section{References}

Baele, L., 2005. Volatility Spillover Effects in European Equity Markets. Journal of Financial and Quantitative Analysis, forthcoming.

Baele, L., Ferrando, A., Hordahl, P., Krylova, E., Monnet, C., 2004. Measuring Financial Integration in the Euro Area. Occasional Paper 14, European Central Bank.

Barr, D.G., Priestley, R., 2004. Expected returns, risk and the integration of international bond markets. Journal of International Money and Finance 23(1), 71-98.

Bekaert, G., Harvey, C.R., 1995. Time-varying world market integration. Journal of Finance 50, 403-444.

Bekaert, G., Harvey, C.R., 2003. Emerging markets finance. Journal of Empirical Finance 10, 3-55.

Bodart, V., Reding, P., 1999. Exchange rate regime, volatility and international correlations on bond and stock markets. Journal of International Money and Finance, 18, 133-151.

Bracker, K., Docking, D., Koch, P., 1999. Economic determinants of evolution in international stock market integration. Journal of Empirical Finance 6, 1-27.

Campbell, J.Y., Ammer, J., 1993. What moves the stock and bond markets? A variance decomposition for long-term asset returns. Journal of Finance 48(1), 3-37.

Cappiello, L., Engle, R.F., Sheppard, K., 2003. Asymmetric dynamics in the correlations of global equity and bond returns. European Central Bank working paper no. 204, Frankfurt am Main.

Chordia, T., Sarkar, A., Subrahmanyam, A., 2005. An Empirical analysis of stock and bond market liquidity. Review of Financial Studies 18(1), 85-129.

Connolly, R., Stivers, C., Sun, L., 2005. Stock market uncertainty and the Stock-Bond Return Relation. Journal of Financial and Quantitative Analysis, forthcoming.

Darbar, S.M., Deb, P., 2002. Cross-market correlations and transmission of information. Journal of Futures Markets 22(11), 1059-82. 
De Santis, G., Gerard, B., Hillion, P., 2003. The relevance of currency risk in the European Monetary Union. International Economics and Business 55, 427-462.

Engle, R. 2002. Dynamic Conditional Correlation-A Simple Class of Multivariate GARCH Models. Journal of Business and Economic Statistics 20, 339-350.

Engle, R., Ng, V.K., 1993. Measuring and testing the impact of news on volatility. Journal of Finance 48, 1749-78.

Engsted, T., Tanggaard, C., 2001. The Danish Stock and Bond markets: Comovement, Return predictability and variance decomposition. Journal of Empirical Finance 8, 243-271.

Fleming, J., Kirby, C., Ostdiek, B., 1998. Information and volume linkages in the stock, bond and money markets. Journal of Financial Economics 49, 111-137.

Fratzscher, M., 2002. Financial market integration in Europe: On the effects of the EMU on stock markets. International Journal of Finance and Economics 7, 165-193.

Galati, G., and Tsatsaronis, K., 2003. The impact of the euro on Europe’s financial markets. Financial Markets, Institutions and Instruments 12(3), 165-221.

Hartmann, P., Straetmans, S., Devries, C., 2004. Asset Market Linkages in Crisis Periods. The Review of Economics and Statistics 86(1), 313-326.

Ilmanen, A., 1995. Time-varying expected returns in international bond markets. Journal of Finance 50(2), 481-506.

Karolyi, G.A., Stulz, R.M., 1996. Why do markets move together? An investigation of U.SJapan stock return comovements. Journal of Finance 51(3), 951-986.

Kim, S-J., Moshirian, F., Wu, E., (In-Press). Dynamic Stock market integration driven by the European Monetary Union: An empirical analysis. Journal of Banking and Finance.

Kodres, L., Pritsker, M., 2002. A rational expectations model of financial contagion. Journal of Finance 57, 769-799.

Kroner, K.F., Ng, V.K., 1998. Modeling asymmetric comovements of asset returns. The 
Review of Financial Studies 11(4), 817-844.

Li, L., 2002. Macroeconomic factors and the correlation of stock and bond returns. Working paper, Yale University.

Longin, F., Solnik, B., 1995. Is the correlation in international equity returns constant:19601990? Journal of International Money and Finance 14(1), 3-26.

Mamaysky, H., 2002. Market prices of risk and return predictability in a joint stock-bond pricing model. Yale International Centre for Finance working paper no. 02-25.

McKinnon, R.I., 1963. Optimum currency areas. American Economic Review, 53, September, 717-725.

Morana, C., Beltratti, A., 2002. The effects of the introduction of the euro on the volatility of European Stock markets. Journal of Banking and Finance 26, 2047-2064.

Mundell, R.A., 1961. A theory of optimum currency areas. American Economic Review, 51, September, 657-65.

Nelson, D.B. (1991). Conditional heteroskedasticity in asset returns: A new approach. Econometrica 59, 347-370.

Prasad, E., Rogoff, K. Wei, S.-J., Kose, M.A., 2003. The effects of financial globalization on developing countries: Some empirical evidence. IMF Occasional paper no. 220.

Scruggs, J.T., Glabadanidis, P., 2003. Risk premia and the dynamic covariance between stock and bond returns. Journal of Financial and Quantitative Analysis 38(2), 295-316.

Smith, K.L., 2002. Government bond market seasonality, diversification, and cointegration: International evidence. Journal of Financial Research 25(2), 203-221.

Veronesi, P., 1999. Stock market overreaction to bad news in good times: A rational expectations equilibrium model. The Review of Financial Studies 12, 975-1007.

Wu, G., 2001. The determinants of asymmetric volatility. The Review of Financial Studies 14(3), 837-859. 
Figure 1. Time-varying integration between Bond and Stock returns: 2/3/1994 -19/9/2003

This figure shows the estimated inter-stock-bond conditional correlations from the bivariate EGARCH- $t$ model. They indicate the evolution of inter-market integration between stock and government bond markets over time for each sample Euro zone country (LHS) and the weighted average of these for Euro land and also non-Euro zone countries (RHS).
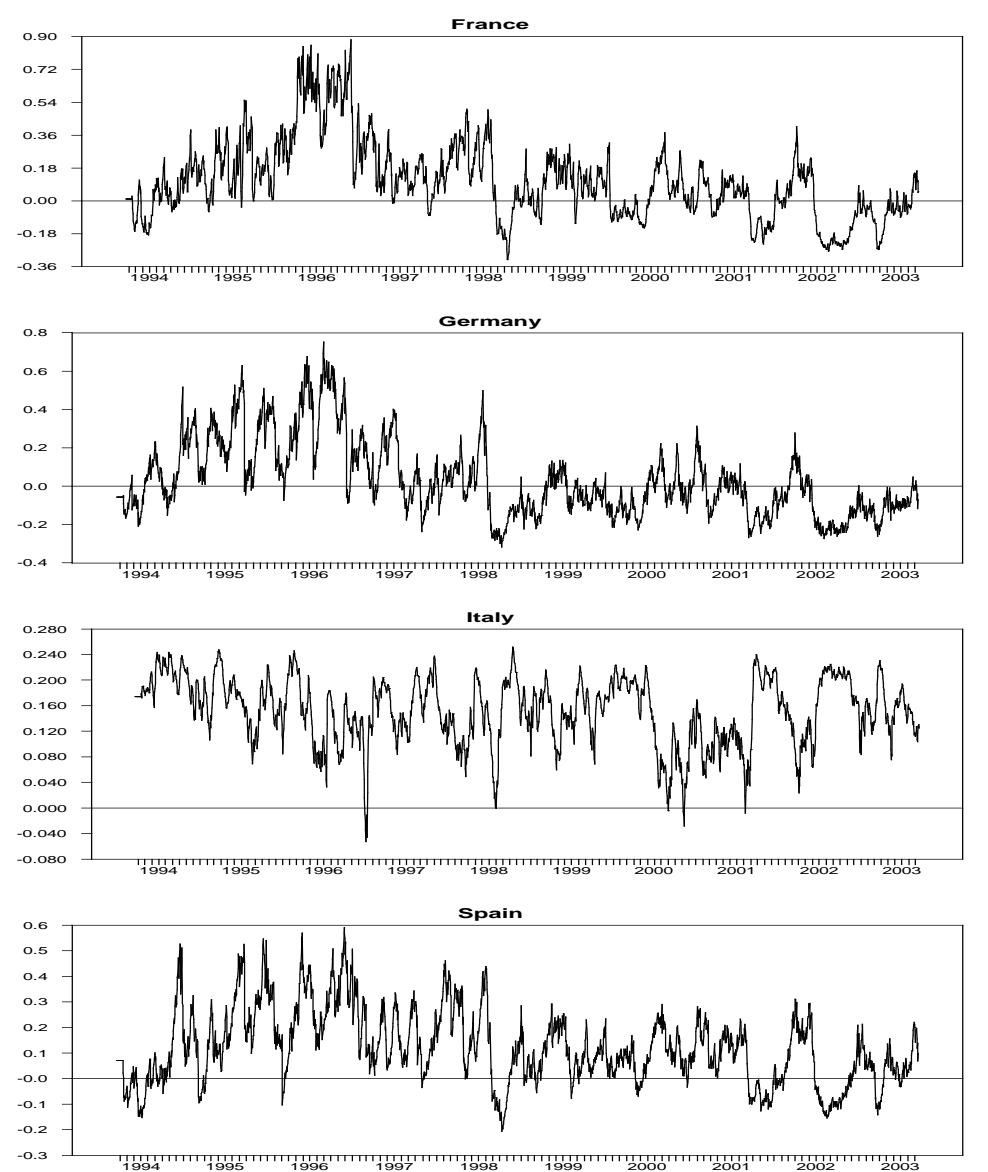
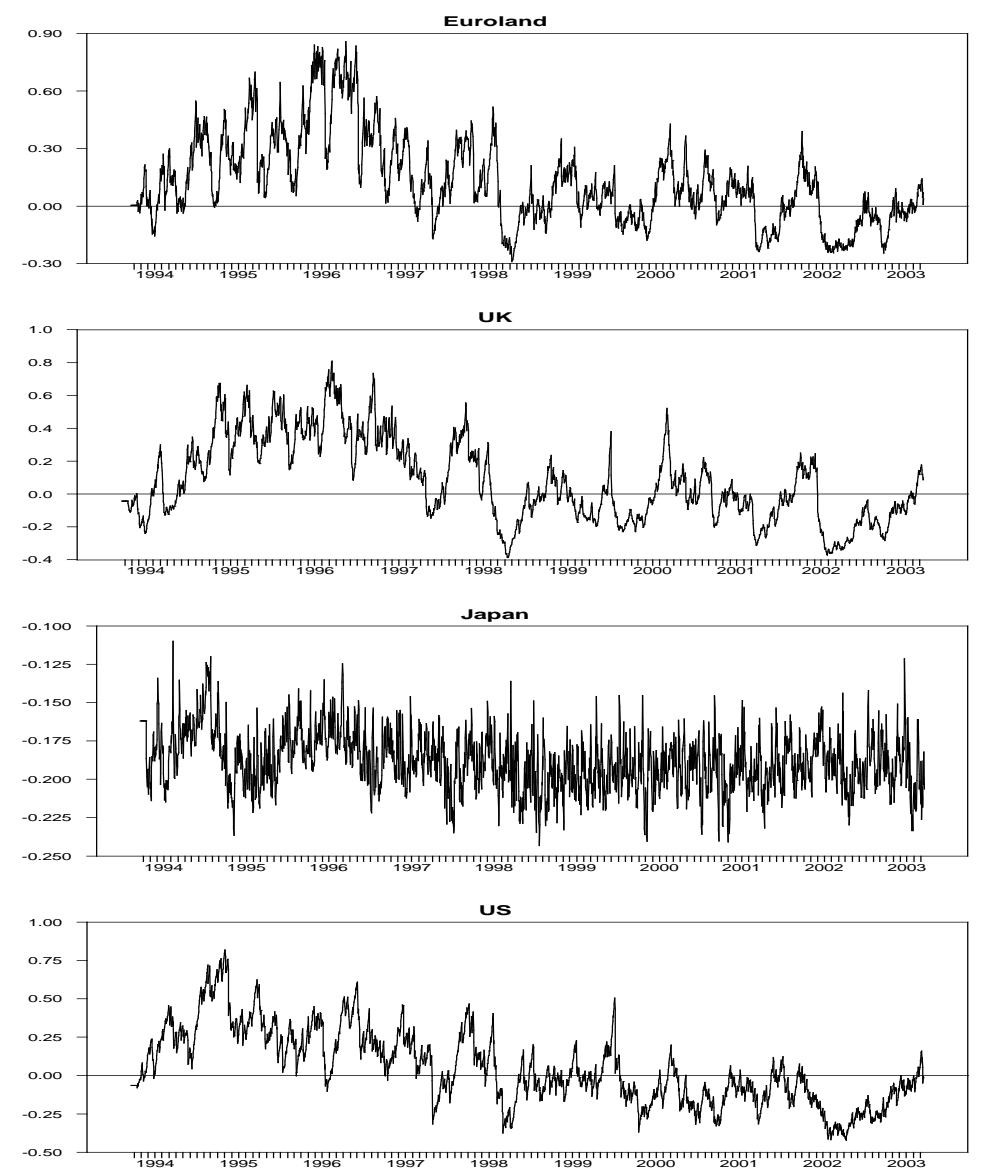
Figure 2. Time varying integration with the EMU in Government Bond (LHS) and Stock (RHS) markets: 2/3/1994 -19/9/2003

This figure illustrates the evolution of intra-market integration with the Euro region for national government bond markets (LHS) and stock markets (RHS) using estimated conditional correlations.
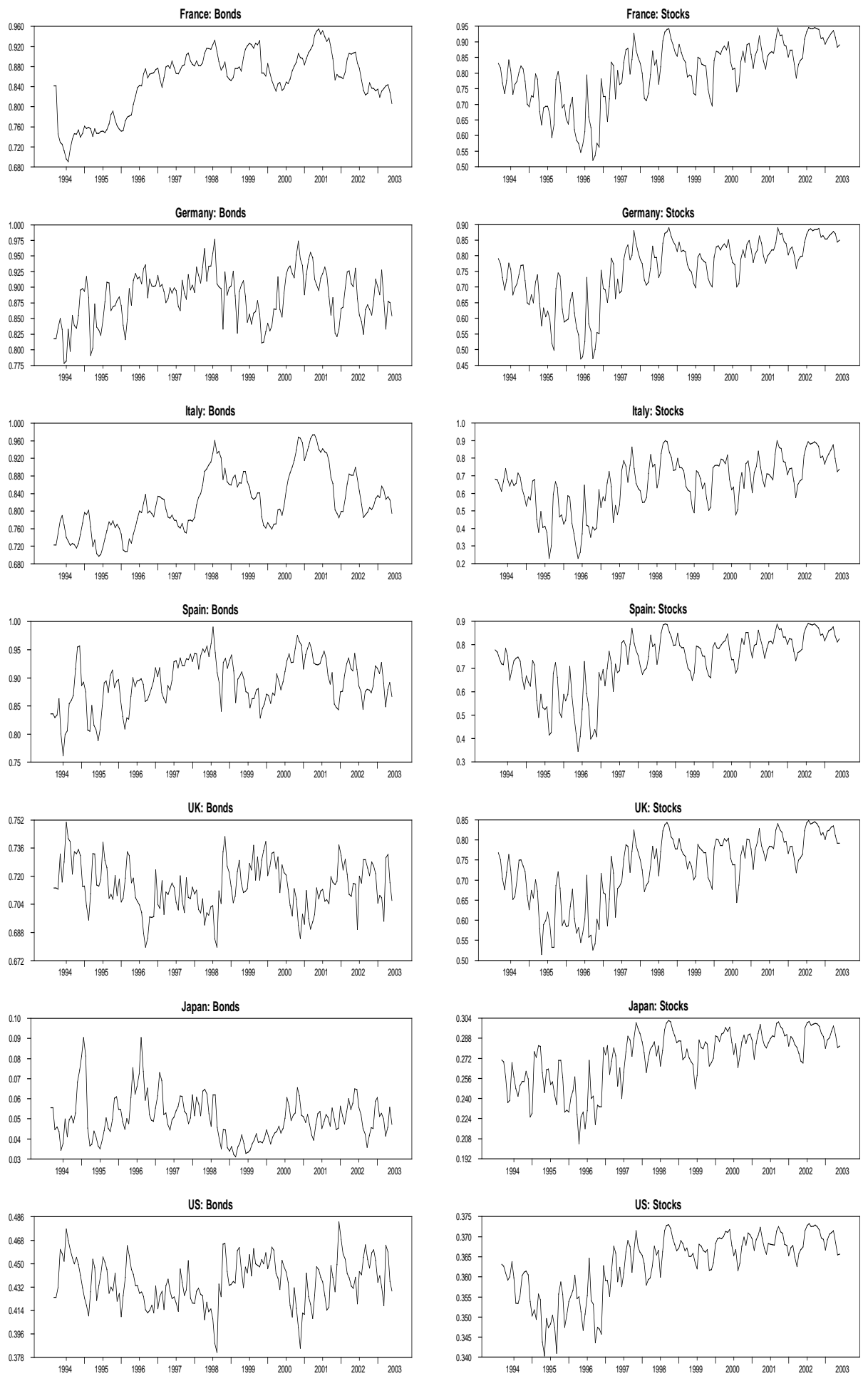


\section{Table 1}

\section{Statistical properties of daily bond and equity returns (\%), 2/3/1994-19/9/2003}

This table presents in panels A and B the summary statistics for the pre- and post-Euro sub-sample periods respectively. Asymptotic p-values are shown in the brackets. *, **, *** denote statistical significance at the 10,5 and $1 \%$ level respectively. Test results for $\mathrm{H}_{0}:$ Skewness $=0$ and $\mathrm{H}_{0}$ :Excess kurtosis=0 are indicated. Q(20) is the Ljung-Box test statistic for serial correlation up to the $20^{\text {th }}$ order in the return series; $\mathrm{Q}^{2}(20)$ is the Ljung-Box test statistic for serial correlation up to the $20^{\text {th }}$ order in the squared returns. $\mathrm{Q}_{b}(20)$ and $\mathrm{Q}_{b}^{2}(20)$ are the bivariate Ljung-Box tests for joint white noise in the linear and squared bond and stock returns up to the $20^{\text {th }}$ order.

\begin{tabular}{|c|c|c|c|c|c|c|c|c|c|c|c|c|c|c|}
\hline & \multicolumn{2}{|c|}{ Bond Index Return } & \multirow[b]{2}{*}{ Skewness } & \multicolumn{3}{|c|}{ Test of univariate iid } & \multicolumn{2}{|c|}{ Stock Index Return } & \multirow[b]{2}{*}{ Skewness } & \multirow[b]{2}{*}{$\begin{array}{l}\text { Excess } \\
\text { Kurtosis }\end{array}$} & \multicolumn{2}{|c|}{ Test of univariate iid } & \multicolumn{2}{|c|}{ Test of bivariate iid } \\
\hline & $\begin{array}{l}\text { Mean } \\
\text { return }\end{array}$ & Variance & & $\begin{array}{c}\text { Excess } \\
\text { Kurtosis }\end{array}$ & $\begin{array}{l}Q(20): \\
\chi^{2}(20)\end{array}$ & $\begin{array}{l}\mathrm{Q}^{2}(20): \\
\chi^{2}(20)\end{array}$ & $\begin{array}{l}\text { Mean } \\
\text { return }\end{array}$ & Variance & & & $\mathrm{Q}(20): \chi^{2}(20)$ & $\mathrm{Q}^{2}(20): \chi^{2}(20)$ & $\begin{array}{l}\mathrm{Q}_{\mathrm{b}}(20): \\
\chi^{2}(80)\end{array}$ & $\begin{array}{c}\mathrm{Q}_{\mathrm{b}}^{2}(20): \\
\chi^{2}(80)\end{array}$ \\
\hline \multicolumn{15}{|c|}{ Panel A: Sub-sample period 1: 2/3/94-31/12/98 } \\
\hline FRA & 0.046 & 0.249 & $-0.256 * * *$ & $3.493 * * *$ & $\begin{array}{c}67.812^{* * *} \\
\{0.000\}\end{array}$ & $\begin{array}{c}524.188^{* * *} \\
\{0.000\}\end{array}$ & 0.060 & 1.095 & $-0.226 * * *$ & $3.137 * * *$ & $\begin{array}{c}47.225^{* * *} \\
\{0.001\}\end{array}$ & $\begin{array}{c}644.323^{* * *} \\
\{0.000\}\end{array}$ & $\begin{array}{c}110.797^{* *} \\
\{0.013\}\end{array}$ & $\begin{array}{c}1261.283^{* * *} \\
\quad\{0.000\}\end{array}$ \\
\hline GER & 0.044 & 0.264 & $-0.703^{* * *}$ & $3.760 * * *$ & $\begin{array}{c}54.657 * * * \\
\{0.000\}\end{array}$ & $\begin{array}{c}251.885^{* * * *} \\
\{0.000\}\end{array}$ & 0.062 & 1.077 & $-0.867 * * *$ & $5.381^{* * *}$ & $\begin{array}{c}81.866^{* * * *} \\
\{0.000\}\end{array}$ & $\begin{array}{c}845.385^{* * *} \\
\{0.000\}\end{array}$ & $\begin{array}{c}142.528 * * * \\
\{0.000\}\end{array}$ & $\begin{array}{c}1095.219 * * * \\
\quad\{0.000\}\end{array}$ \\
\hline ITA & 0.078 & 0.430 & $-0.820 * * *$ & $4.877 * * *$ & $\begin{array}{c}52.439 * * * \\
\{0.000\}\end{array}$ & $\begin{array}{c}138.287^{* * *} \\
\quad\{0.000\}\end{array}$ & 0.070 & 1.976 & -0.094 & $2.157 * * *$ & $\begin{array}{c}50.538^{* * *} \\
\{0.000\}\end{array}$ & $\begin{array}{c}655.480 * * * \\
\{0.000\}\end{array}$ & $\begin{array}{c}93.504 \\
\{0.143\}\end{array}$ & $\begin{array}{c}900.643^{* * *} \\
\{0.000\}\end{array}$ \\
\hline SPA & 0.061 & 0.261 & $-0.482 * * *$ & $3.733 * * *$ & $\begin{array}{c}79.233^{* * *} \\
\{0.000\}\end{array}$ & $\begin{array}{c}325.431^{* * *} \\
\{0.000\}\end{array}$ & 0.090 & 1.369 & $-0.561 * * *$ & $4.205^{* * *}$ & $\begin{array}{c}84.546 * * * \\
\{0.000\}\end{array}$ & $\begin{array}{c}936.326 * * * \\
\{0.000\}\end{array}$ & $\begin{array}{c}168.617 * * * \\
\{0.000\}\end{array}$ & $\begin{array}{c}1397.832 * * * \\
\{0.000\}\end{array}$ \\
\hline $\mathrm{EMU}^{\bullet}$ & 0.058 & 0.220 & $-0.694 * * *$ & $3.025^{* * *}$ & $\begin{array}{c}84.056^{* * *} \\
\{0.000\}\end{array}$ & $\begin{array}{c}166.973 * * * \\
\{0.000\}\end{array}$ & 0.068 & 0.922 & $-0.637 * * *$ & $5.097 * * *$ & $\begin{array}{c}95.543 * * * \\
\{0.000\}\end{array}$ & $\begin{array}{c}1124.467^{* * *} \\
\quad\{0.000\}\end{array}$ & $\begin{array}{c}187.665 * * * \\
\quad\{0.000\}\end{array}$ & $\begin{array}{c}1336.299^{* * *} \\
\{0.000\}\end{array}$ \\
\hline UK & 0.050 & 0.267 & $-0.355^{* * *}$ & $3.959 * * *$ & $\begin{array}{c}38.916 * * * \\
\{0.007\}\end{array}$ & $\begin{array}{c}143.838^{* * * *} \\
\{0.000\}\end{array}$ & 0.056 & 0.629 & $-0.227 * * *$ & $2.500 * * *$ & $\begin{array}{c}52.017^{* * * *} \\
\{0.000\}\end{array}$ & $\begin{array}{c}1208.309^{* * *} \\
\{0.000\}\end{array}$ & $\begin{array}{c}112.953^{* * *} \\
\{0.009\}\end{array}$ & $\begin{array}{c}1355.691 * * * \\
\quad\{0.000\}\end{array}$ \\
\hline US & 0.039 & 0.288 & $-0.291 * * *$ & $1.534^{* * *}$ & $\begin{array}{c}35.606 * * \\
\{0.017\}\end{array}$ & $\begin{array}{c}60.104^{* * *} \\
\{0.000\}\end{array}$ & 0.088 & 0.769 & $-0.759 * * *$ & $8.737 * * *$ & $\begin{array}{l}31.309^{*} \\
\{0.051\}\end{array}$ & $\begin{array}{c}302.357 * * * \\
\{0.000\}\end{array}$ & $\begin{array}{l}75.673 \\
\{0.616\}\end{array}$ & $\begin{array}{c}385.556 * * * \\
\{0.000\}\end{array}$ \\
\hline JAP & 0.034 & 0.132 & $-0.825 * * *$ & $7.256^{* * *}$ & $\begin{array}{c}61.743^{* * *} \\
\{0.000\}\end{array}$ & $\begin{array}{c}261.910^{* * *} \\
\{0.000\}\end{array}$ & -0.025 & 1.133 & $0.251^{* * *}$ & $3.810 * * *$ & $\begin{array}{c}41.131^{* * *} \\
\{0.004\}\end{array}$ & $\begin{array}{c}361.192^{* * *} \\
\{0.000\} \\
\end{array}$ & $\begin{array}{c}119.711^{* * *} \\
\{0.003\} \\
\end{array}$ & $\begin{array}{c}629.910^{* * *} \\
\{0.000\} \\
\end{array}$ \\
\hline \multicolumn{15}{|c|}{ Panel B: Sub-sample period 2: 1/1/99-19/9/03 } \\
\hline FRA & 0.019 & 0.225 & $-0.327^{* * *}$ & $1.374^{* * *}$ & $\begin{array}{l}26.600 \\
\{0.147\}\end{array}$ & $\begin{array}{c}97.131 * * * \\
\{0.000\}\end{array}$ & 0.006 & 2.262 & -0.056 & $1.575^{* * *}$ & $\begin{array}{c}36.789 * * \\
\{0.012\}\end{array}$ & $\begin{array}{c}689.908^{* * *} \\
\{0.000\}\end{array}$ & $\begin{array}{c}245.951 * * * \\
\quad\{0.000\}\end{array}$ & $\begin{array}{c}1663.977^{* * *} \\
\{0.000\}\end{array}$ \\
\hline GER & 0.019 & 0.288 & $-0.273 * * *$ & $1.109 * * *$ & $\begin{array}{l}31.182^{*} \\
\{0.053\}\end{array}$ & $\begin{array}{c}96.063^{* * *} \\
\{0.000\}\end{array}$ & -0.018 & 2.109 & -0.084 & $1.211^{* * *}$ & $\begin{array}{c}36.631^{* *} \\
\{0.013\}\end{array}$ & $\begin{array}{c}528.853^{* * *} \\
\{0.000\}\end{array}$ & $\begin{array}{c}164.583^{* * *} \\
\{0.000\}\end{array}$ & $\begin{array}{c}1308.812^{* * *} \\
\{0.000\}\end{array}$ \\
\hline ITA & 0.020 & 0.251 & $-0.315 * * *$ & $1.371^{* * *}$ & $\begin{array}{c}31.628^{* *} \\
\{0.047\}\end{array}$ & $\begin{array}{c}147.812^{* * *} \\
\{0.000\}\end{array}$ & -0.009 & 1.850 & $-0.170 * *$ & $2.355^{* * *}$ & $\begin{array}{l}30.726^{*} \\
\{0.059\}\end{array}$ & $\begin{array}{c}515.490^{* * *} \\
\{0.000\}\end{array}$ & $\begin{array}{c}155.836 * * * \\
\{0.000\}\end{array}$ & $\begin{array}{c}1378.411^{* * *} \\
\quad\{0.000\}\end{array}$ \\
\hline SPA & 0.020 & 0.194 & $-0.347 * * *$ & $1.342^{* * *}$ & $\begin{array}{l}29.678 * \\
\{0.075\}\end{array}$ & $\begin{array}{c}110.416^{* * *} \\
\{0.000\}\end{array}$ & -0.009 & 1.852 & 0.010 & $1.220^{* * *}$ & $\begin{array}{l}24.010 \\
\{0.242\}\end{array}$ & $\begin{array}{c}547.439^{* * *} \\
\{0.000\}\end{array}$ & $\begin{array}{c}128.812^{* * *} \\
\{0.000\}\end{array}$ & $\begin{array}{c}1428.634^{* * *} \\
\{0.000\}\end{array}$ \\
\hline EMU ${ }^{\bullet}$ & 0.019 & 0.243 & $-0.315 * * *$ & $1.142^{* * *}$ & $\begin{array}{c}31.441^{* *} \\
\{0.050\}\end{array}$ & $\begin{array}{c}116.862 * * * \\
\{0.000\}\end{array}$ & -0.005 & 1.844 & -0.106 & $1.568 * * *$ & $\begin{array}{c}35.882 * * \\
\{0.016\}\end{array}$ & $\begin{array}{c}610.903 * * * \\
\{0.000\}\end{array}$ & $\begin{array}{c}149.452^{* * *} \\
\{0.000\}\end{array}$ & $\begin{array}{c}1524.872^{* * *} \\
\quad\{0.000\}\end{array}$ \\
\hline UK & 0.014 & 0.238 & -0.115 & $0.480 * * *$ & $\begin{array}{c}32.796 * * \\
\{0.036\}\end{array}$ & $\begin{array}{c}37.010^{* *} \\
\{0.012\}\end{array}$ & -0.008 & 1.505 & $-0.174^{* *}$ & $1.761^{* * *}$ & $\begin{array}{c}56.114^{* * * *} \\
\{0.000\}\end{array}$ & $\begin{array}{c}904.504^{* * *} \\
\{0.000\}\end{array}$ & $\begin{array}{c}190.468 * * * \\
\{0.000\}\end{array}$ & $\begin{array}{c}1959.335 * * * \\
\quad\{0.000\}\end{array}$ \\
\hline US & 0.024 & 0.349 & $-0.455 * * *$ & $0.756^{* * *}$ & $\begin{array}{c}17.218 \\
\{0.639\}\end{array}$ & $\begin{array}{c}80.426^{* * *} \\
\{0.000\}\end{array}$ & -0.009 & 1.856 & $0.125^{*}$ & $1.425^{* * *}$ & $\begin{array}{c}26.950 \\
\{0.137\}\end{array}$ & $\begin{array}{c}232.404 * * * \\
\{0.000\}\end{array}$ & $\begin{array}{c}123.713^{* * *} \\
\{0.001\}\end{array}$ & $\begin{array}{c}698.711^{* * *} \\
\{0.000\}\end{array}$ \\
\hline JAP & 0.019 & 0.225 & $-0.729 * * *$ & $5.982^{* * *}$ & $\begin{array}{c}48.229 * * * \\
\{0.000\}\end{array}$ & $\begin{array}{c}501.105^{* * *} \\
\{0.000\}\end{array}$ & 0.004 & 1.720 & $-0.159 * *$ & $1.519^{* * *}$ & $\begin{array}{l}26.980 \\
\{0.136\}\end{array}$ & $\begin{array}{c}66.161^{* * *} \\
\{0.000\}\end{array}$ & $\begin{array}{c}170.321 * * * \\
\{0.000\}\end{array}$ & $\begin{array}{c}1204.029 * * * \\
\{0.000\}\end{array}$ \\
\hline
\end{tabular}

'Stock and bond market returns for the entire EMU are calculated as the value weighted average return of the 4 sample Euro zone markets. The weights used for stock and bond returns are stock market capitalization values from Datastream and annual government gross liabilities sourced from the OECD respectively 
Table 2

Bivariate-ARMA-EGARCH-t Model Estimations for bond and stock returns with conditional volatility spillovers

In this table, the results of the bivariate EGARCH estimations are reported. The bivariate EGARCH model for each country, as defined in equations $(1 \mathrm{a}, \mathrm{b})$ and $(2 \mathrm{a}, \mathrm{b})$ is:

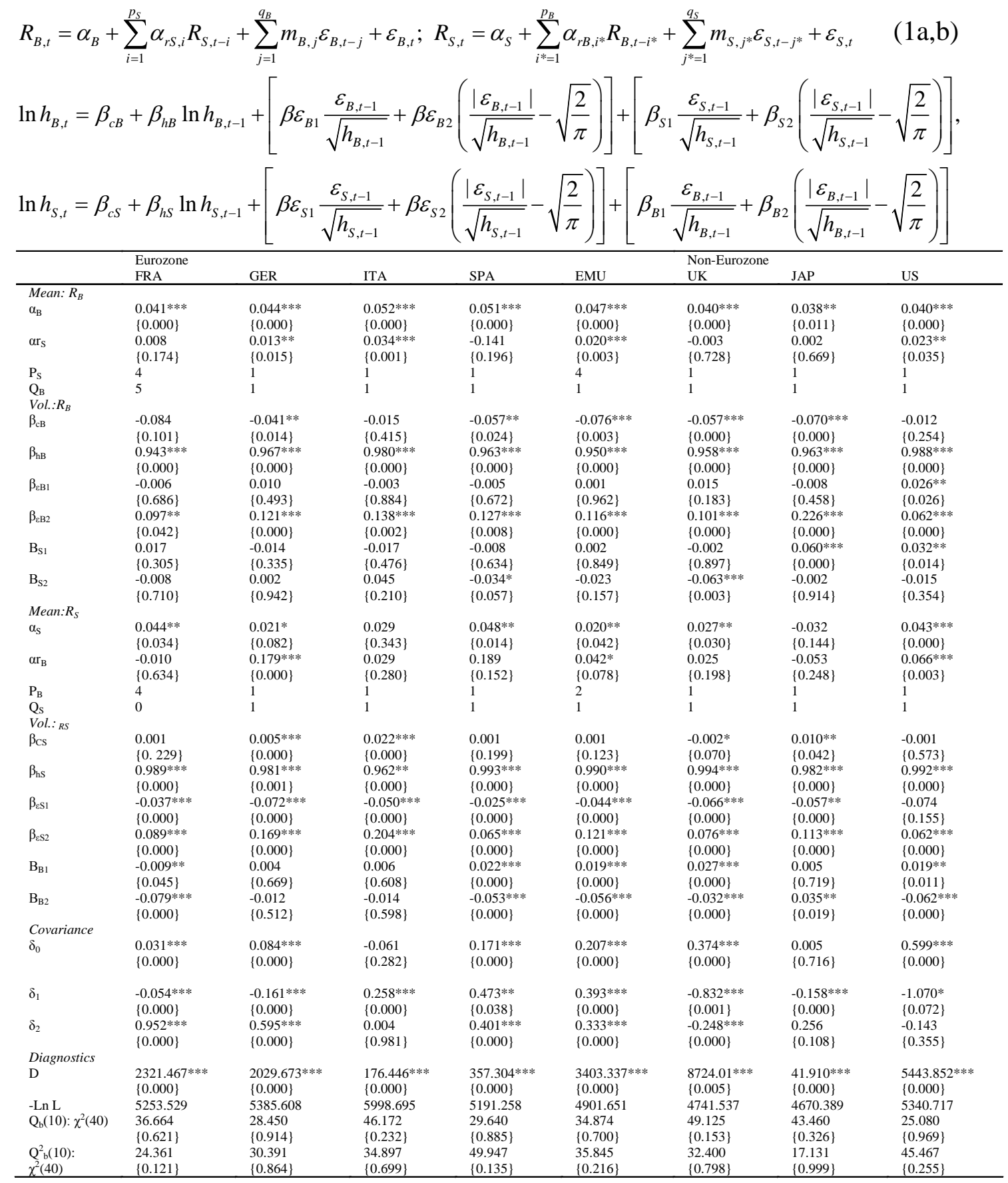

Notes: $D$ is the degree of freedom in a student $t$ distribution for the two joint error processes. - Ln $L$ is the negative estimated value of log-likelihood. P-Values are shown in the brackets.*,**,*** denote significance at the $10 \%, 5 \%$ and $1 \%$ level respectively. $Q_{b}(10)$ and $Q^{2}{ }_{b}(10)$ are the bivariate Ljung-Box $Q$ tests for joint white noise in the linear and squared standardized residuals ( $z_{t}$ 's and $z_{t}^{2}$ 's) up to the $10^{\text {th }}$ order. 


\section{Table 3}

\section{Granger Causality Test Results}

In this table, results of the Granger-causality tests between inter-stock-bond market integration $\left(\rho_{B S}\right)$ and the implementation of the EMU (EMU) are reported for all countries in the Euro zone and the results for the UK, Japan and the US are reported separately in panel B. $\rho_{B S i, t}$ are the estimated conditional correlation time series and $E M U_{t}$ are the correlations in nominal short term interest rates with the Euro zone equivalent. Asymptotic pvalues are shown in the brackets. ${ }^{*}, * *, * * *$ denote statistical significance at the 10,5 and $1 \%$ level respectively.

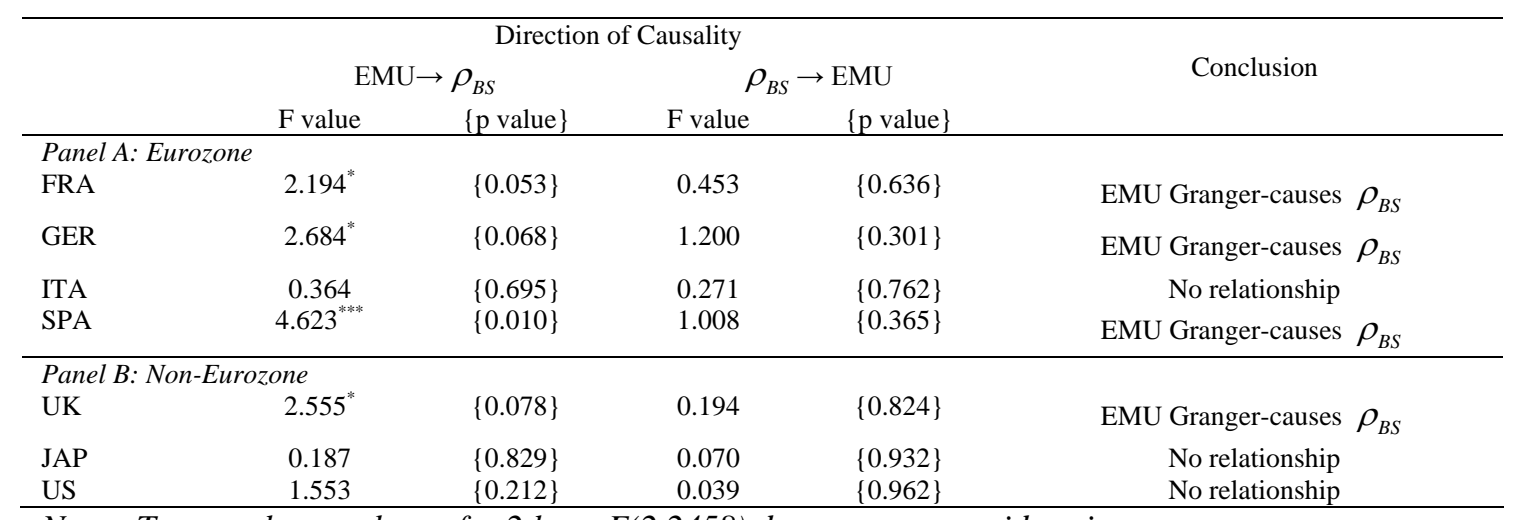

Note: Test results are shown for 2 lags, F(2,2458) due to space considerations. 


\section{Table 4}

Regression results for the sample period 1/4/1994 to 19/9/2003

In this table, the seemingly unrelated regression (SUR) estimates are shown. The model estimated is defined in equation (5):

$$
\rho_{B S i, t}=\alpha_{1 i}+\alpha_{2 i} E X_{-} V O L_{i, t-1}+\alpha_{3 i} R E A L_{-} I N T_{i, t-1}+\alpha_{4 i} M O N_{-} I N T_{i, t-1}+\alpha_{5 i} J A N_{-} D U M_{i, t}+\alpha_{6 i} \rho_{B S i, t-1}+\alpha_{7 i} \rho_{B S i, t-2}+u_{i t}(5)
$$

where the dependent variable ( $\left.\rho_{B S i, t}\right)$ is the estimated conditional correlation series for each country $i$, $E X_{-} V O L_{i, t-1}=$ lagged conditional exchange rate volatility, $R E A L_{-} I N T_{i, t-1}=$ lagged real economic convergence, $M O N \_I N T_{i, t-1}=$ lagged monetary policy convergence and JAN_DUM is the January dummy variable, and

$\rho_{B S i, t-1}$ and $\rho_{B S i, t-2}$ are the first and second lags of the dependent variable.

\begin{tabular}{|c|c|c|c|c|c|c|c|}
\hline & \multicolumn{4}{|l|}{ Euro zone } & \multicolumn{3}{|c|}{ Non-euro zone } \\
\hline & FRA & GER & ITA & SPA & UK & JAP & US \\
\hline \multirow[t]{2}{*}{ CONSTANT } & $0.0112 * * *$ & $0.0113 * * *$ & $0.0046^{* * *}$ & $0.0064 * *$ & -0.0002 & $-0.0402 * * *$ & 0.0011 \\
\hline & $\{0.0067\}$ & $\{0.0028\}$ & $\{0.0000\}$ & $\{0.0199\}$ & $\{0.9520\}$ & $\{0.0000\}$ & $\{0.5991\}$ \\
\hline \multirow[t]{2}{*}{ EX_VOL ${ }_{t-1}$} & -0.0024 & $-0.0035^{*}$ & -0.0005 & 0.0009 & 0.0024 & $-0.0027 * * *$ & 0.0029 \\
\hline & $\{0.1368\}$ & $\{0.0520\}$ & $\{0.3557\}$ & $\{0.5925\}$ & $\{0.2410\}$ & $\{0.0000\}$ & $\{0.4753\}$ \\
\hline \multirow[t]{2}{*}{ REAL_INT ${ }_{\mathrm{t}-1}$} & $0.0060 * *$ & 0.0036 & $0.0009 * *$ & 0.0022 & 0.0004 & $0.0010 * *$ & $0.0023^{*}$ \\
\hline & $\{0.0456\}$ & $\{0.1426\}$ & $\{0.0176\}$ & $\{0.2144\}$ & $\{0.8493\}$ & $\{0.0167\}$ & $\{0.0898\}$ \\
\hline \multirow[t]{2}{*}{ MON_INT $\mathrm{t}_{\mathrm{t}-1}$} & -0.0015 & 0.0017 & $0.0006^{*}$ & 0.0003 & 0.0001 & -0.0003 & 0.0009 \\
\hline & $\{0.3644\}$ & $\{0.1933\}$ & $\{0.0666\}$ & $\{0.7315\}$ & $\{0.9313\}$ & $\{0.3137\}$ & $\{0.3904\}$ \\
\hline \multirow[t]{3}{*}{ JAN_DUM } & -0.0012 & 0.0007 & 0.0009 & -0.0017 & -0.0006 & 0.0004 & -0.0040 \\
\hline & $\{0.6931\}$ & $\{0.8317\}$ & $\{0.1929\}$ & $\{0.4833\}$ & $\{0.7956\}$ & $\{0.6202\}$ & $\{0.1736\}$ \\
\hline & $1.0924 * * *$ & $0.7179 * * *$ & $1.2900 * * *$ & $0.8417 * * *$ & $1.1365 * * *$ & $0.7397 * * *$ & $0.8599 * * *$ \\
\hline \multirow[t]{2}{*}{$\rho_{B S i, t-1}$} & $\{0.0000\}$ & $\{0.0000\}$ & $\{0.0000\}$ & $\{0.0000\}$ & $\{0.0000\}$ & $\{0.0000\}$ & $\{0.0000\}$ \\
\hline & $-0.1276^{* * *}$ & $0.2460 * * *$ & $-0.3162 * * *$ & $0.1222 * * *$ & $-0.1508 * * *$ & 0.0315 & $0.1218 * * *$ \\
\hline$\rho_{B S i, t-2}$ & $\{0.0000\}$ & $\{0.0000\}$ & $\{0.0000\}$ & $\{0.0000\}$ & $\{0.0000\}$ & $\{0.1122\}$ & $\{0.0000\}$ \\
\hline \multirow{4}{*}{$\begin{array}{l}\text { Adj. } \mathrm{R}^{2} \\
\text { ADF Test Statistic } \\
\text { Q Test }\left(\sim \chi^{2}{ }_{20}\right)\end{array}$} & 0.9652 & 0.9533 & 0.9688 & 0.9467 & 0.9857 & 0.6211 & 0.9745 \\
\hline & $-5.5404^{* *}$ & $-5.4901 * *$ & $-6.4788 * *$ & $-5.7078 * *$ & $-4.2833 * *$ & $-13.1336 * *$ & $-5.6143 * *$ \\
\hline & $42.1518 * * *$ & 21.4509 & 14.0052 & 21.1950 & 19.7899 & $37.5019 * *$ & $41.6225 * * *$ \\
\hline & $\{0.0026\}$ & $\{0.3710\}$ & $\{0.8302\}$ & $\{0.3859\}$ & $\{0.4711\}$ & $\{0.0102\}$ & $\{0.0031\}$ \\
\hline \multirow[t]{2}{*}{ Chow test $\left(\chi^{2}{ }_{7}\right)$} & $15.3671 * *$ & $30.3336 * * *$ & $27.3391 * * *$ & 8.7813 & $13.0759 *$ & $68.5809 * * *$ & $19.9231 * * *$ \\
\hline & $\{0.0316\}$ & $\{0.0001\}$ & $\{0.0003\}$ & $\{0.2687\}$ & $\{0.0703\}$ & $\{0.0000\}$ & $\{0.0057\}$ \\
\hline No. obs. & 2469 & 2469 & 2469 & 2469 & 2469 & 2469 & 2469 \\
\hline
\end{tabular}

Notes: $P$ values are shown in brackets and $*, * *, * * *$ denote significance at the $10 \%$, 5\% and $1 \%$ level respectively. The ADF test included a constant, trend and 4 lags and the critical value at the 5\% significance level for the null hypothesis of a unit root is -3.410. The Ljung Box Q test is for a null hypothesis of no serial correlation up to the $20^{\text {th }}$ order. The Chow test is for a null hypothesis of no structural change from the $1^{\text {st }}$ January, 1999. 
Appendix A

Variable Definitions and Data Sources

\begin{tabular}{|c|c|c|c|c|}
\hline Category & Variable & Frequency & Source & Definition \\
\hline \multirow[t]{2}{*}{ Exchange Rate risk } & EX_VOL & Daily & Datastream & $\begin{array}{l}\text { Conditional variance from a GARCH(1,1) } \\
\text { model for daily local currency to Euro } \\
\text { exchange returns. }\end{array}$ \\
\hline & EX_SD* & Daily & Datastream & $\begin{array}{l}\text { Rolling standard deviations of daily changes } \\
\text { in the foreign exchange rate over the past } 3 \\
\text { months (quarter). }\end{array}$ \\
\hline \multirow[t]{5}{*}{ Real Convergence } & OUTPUT & Monthly & IMF/Eurostat & $\begin{array}{l}\text { Rolling correlations in annual growth rates } \\
\text { of seasonally adjusted industrial production } \\
\text { (IP) with the Euroarea equivalent (weighted } \\
\text { by annual GDP share prior to Jan. 1999) } \\
\text { over the past } 3 \text { months (quarter). }\end{array}$ \\
\hline & TERM_STRUC & Daily & Datastream & $\begin{array}{l}\text { Rolling correlations in the term structure } \\
\text { changes (long-term benchmark rates - } 1 \\
\text { month LIBOR rates) with Euro area } \\
\text { equivalent (weighted by annual GDP share } \\
\text { prior to Jan. 1999) over the past } 3 \text { months } \\
\text { (quarter). }\end{array}$ \\
\hline & DIV_YIELD & Daily & Datastream & $\begin{array}{l}\text { Rolling correlations for changes in dividend } \\
\text { yields with the Euro area equivalent } \\
\text { (weighted by stock market capitalization) } \\
\text { over the past } 3 \text { months (quarter). }\end{array}$ \\
\hline & TRADE_OPEN & Monthly & Datastream/IMF & $\begin{array}{l}\text { Ratio of total exports plus imports to annual } \\
\text { GDP }\end{array}$ \\
\hline & TRADE_INT & Monthly & Datastream & $\begin{array}{l}\text { Ratio of exports plus imports to/from } \\
\text { EMU/EU to total trade }\end{array}$ \\
\hline \multirow[t]{3}{*}{$\begin{array}{l}\text { Monetary Policy } \\
\text { Convergence }\end{array}$} & NOM_SRATE & Daily & Datastream and IMF & $\begin{array}{l}\text { Rolling correlations in nominal short-term } \\
\text { interest rates ( } 1 \text { month LIBOR rates) with } \\
\text { the Euro area equivalent (weighted by } \\
\text { annual GDP share prior toJan.1998) over the } \\
\text { past } 3 \text { months. }\end{array}$ \\
\hline & INFLA & Monthly & $\begin{array}{l}\text { Datastream } \\
\text { and IMF }\end{array}$ & $\begin{array}{l}\text { Rolling correlations in seasonally-adjusted } \\
\text { consumer price inflation with the Euro-area } \\
\text { equivalent (weighted by annual GDP prior to } \\
\text { Jan.1998) over the past 3months. }\end{array}$ \\
\hline & REAL_SRATE & Monthly & Datastream and IMF & $\begin{array}{l}\text { Rolling correlations in real short-term } \\
\text { interest rates (1 month LIBOR rates - } \\
\text { inflation) with the Euro area equivalent } \\
\text { (weighted by annual GDP share prior to Jan. } \\
\text { 1998). }\end{array}$ \\
\hline \multirow[t]{7}{*}{ Control } & FRI_DUM* & Daily & & $\begin{array}{l}\text { Indicator is equal to one if that trading day } \\
\text { was a Friday, zero otherwise. }\end{array}$ \\
\hline & MON_DUM* & Daily & & $\begin{array}{l}\text { Indicator is equal to one if that trading day } \\
\text { was a Monday, zero otherwise. }\end{array}$ \\
\hline & JAN_DUM & Daily & & $\begin{array}{l}\text { Indicator is equal to one if that trading day } \\
\text { was in January, zero otherwise. }\end{array}$ \\
\hline & EURO_DUM ${ }^{* * * *}$ & Daily & & $\begin{array}{l}\text { Indicator takes a value of one if the Euro has } \\
\text { already been introduced on the date ie. from } \\
\text { 1st January } 1999 \text { onwards, zero otherwise. }\end{array}$ \\
\hline & $\mathrm{DIV}^{*}$ & Daily & Datastream & $\begin{array}{l}\text { Dividend yield levels used to construct } \\
\text { DIV_YIELD. }\end{array}$ \\
\hline & ST_IRATE* & Daily & Datastream & $\begin{array}{l}\text { Nominal short-term interest rates used to } \\
\text { construct NOM_SRATE. }\end{array}$ \\
\hline & TERM* & Daily & Datastream & $\begin{array}{l}\text { Term spreads used to construct } \\
\text { TERM_STRUC. }\end{array}$ \\
\hline $\begin{array}{l}\text { Economic } \\
\text { Uncertainty }\end{array}$ & UNCERT & Daily & Datastream & $\begin{array}{l}\text { Natural logarithm of implied volatilities } \\
\text { from equity options index from the Chicago } \\
\text { Board of Options Exchange and the German } \\
\text { DAX. }\end{array}$ \\
\hline
\end{tabular}

* These variables have not been shown in the final model to minimize multicollinearity problems. **Used for the Chow test. 